\title{
Thinking on Innovation of Educational Methods for Occupational Skills of Normal University Students
}

\author{
Xiaoling Zhang \\ Adult Education Department, Leshan Normal University, Leshan, 614000, China
}

Keywords: Teacher training major in colleges and universities. Occupational skills. Educational method

\begin{abstract}
With the rapid development of information technology, teacher training major in colleges and universities has higher and higher requirements for occupational skills of students, such as language skills, head teacher skills and computer skills. Colleges and universities must make close connection with the reality in the training of occupational skills of normal university students, focus on the training of occupational skills on the basis of strengthening the training of students' basic knowledge and skills, make students master their own positioning, attach importance to the training of practical skill level, convey more teacher talents with high skills to the society and promote the improvement of basic educational level in China. This paper conducts detailed discussions on relevant contents of educational methods for occupational skills of normal university students.
\end{abstract}

\section{Introduction}

With the development of modern educational idea and basic education career, educators must constantly improve their own quality, learn to use modern educational concept and methods and improve the teaching level. Normal university students are teacher-to-be. It is required to strengthen the training of their occupational skills and allow them to master solid basic theoretical knowledge and meanwhile have certain practical ability, constantly improve the level of occupational skills with the development of educational career and improve the teaching effect. Therefore, colleges and universities must attach importance to the educational of occupational skills of students in teacher training major.

\section{Requisite occupational skills of students in teacher training major}

Requisite occupational skills of students in teacher training major are requisite educational skills when they are occupied in teaching profession in the future. Specifically speaking, there are such requisite occupational skills as below:

\section{Teaching skills}

Teaching skills are the most basic skills, generally including lesson preparation, prelection and coaching. Lesson preparation skill means that students in teacher training major can plan the teaching design in this whole semester, conduct teaching design of each lesson well and determine teaching objectives of each lesson and unit and overall teaching objectives according to the textbook, teacher's book and teaching contents; select an appropriate teaching method and arrange the prelection, discussion and question raising in each class reasonably according to students' characteristics and teaching contents. Prelection means that students in teacher training major should possess certain skills of giving a new lesson and reviewing old lessons, including skills of language expression, question raising, comment, writing on the blackboard, CAI courseware use and multimedia teaching tool use. Coaching skill means that they can give certain instruction after class according to students' needs and comment on students' examination. Among these three skills, lesson preparation skill is the basis of prelection skill and coaching skill is the basis of giving a good lesson.

\section{Head teacher working skill}

Head teacher working is very complicated. It is required to manage the study and life of dozens of students in a class, comprehensively master psychological features of each student, conduct daily 
class order management work of head teacher and psychological and learning guidance work of students with learning difficulties and less advanced students, conduct coordination work between head teacher and subject teachers and family visit work and evaluate the academic performance and attitude towards learning of each student objectively.

\section{Computer skill}

Computer is an important teaching tool in the current education. Computer skill becomes one of the requisite skills of students in teacher training major. Colleges and universities should strengthen theoretical and practical teaching of computer, improve the computer application ability and operational capacity of students in teacher training major, allow them to use computer to make basic multimedia courseware and master principles of courseware making.

\section{Language expression skill}

Language expression skill is the most basic occupational skill, including mandarin, oral expression skill, written expression skill and pen writing, chalk writing and brush pen writing skills. Mandarin means that students in teacher training major must speak fluent mandarin. Oral expression skill requires students to express what they think fluently, smoothly and briefly and make others understand their words at the first time. Written expression skill is corresponding to oral expression skill but they are connected with each other and different. Pen writing, chalk writing and brush pen writing skills mean that teachers should be able to write Chinese characters with pen, chalk and brush pen.

\section{Problems existing in education of occupational skills of normal university students}

Strengthening the education of occupational skills is an important means for improving students' occupational skill level and promoting their smooth employment and meanwhile can convey more qualified educators to the society and promote the development of Chinese educational business. However, there are many problems in the education of occupational skills of normal university students, which restrain the improvement of students' occupational skills to a certain extent.

\section{Attach importance to theoretical education but neglect the education of occupational skills}

Teacher training major in colleges and universities has many courses. Colleges and universities attach importance to the teaching of theoretical course but neglect the teaching of occupational skills.

First, curriculum setting is partial to basic, academic and research-oriented courses. There are fewer practical and applied courses. Teaching contents are obsolete and are not closely connected with the reality. The curriculum system is unreasonable.

Second, few "double-role” teachers. Many college teachers lack the experience of teaching in primary school and secondary school and do not understand the educational status in primary school and secondary school. Therefore, they cannot provide high-level practical teaching for students in teaching.

Third, single teaching mode. The teaching mode mainly involves prelection of teachers in class and students listening to the class. It fails to stimulate the learning initiative of students and causes poor teaching effect.

Forth, few evaluation indicators. When evaluating students, colleges and universities only pay attention to students' mastery of theoretical knowledge rather than their mastery of occupational skills. Language expression ability, head teacher skill, organizing ability and teaching design ability of many normal university students are inferior to those graduated from secondary vocational normal schools.

\section{Lack of practical teaching conditions}

First, no basic experimental facilities. Many colleges and universities do not supply audio-visual classroom and microteaching classroom according to professional features of students in teacher training major. Conditions for practical teaching are inadequate.

Second, theoretical teaching is not combined with practical teaching perfectly. Many courses are pure theoretical courses and do not have practical course links such as social practice, internship and probation. 
Third, incomplete practical teaching evaluation mechanism. The evaluation of practical teaching is often completed by the subject teacher alone only with a simple score. It does not manifest students' progress and shortages or stimulate students' initiative. The teaching effect is limited.

\section{Lack of emphasis in the training of occupational skills}

Though many colleges and universities design teaching contents of the training of occupational skills according to students' professional features, as there are too many occupational skills to be mastered by students and schools easily go into the misunderstanding of wide generalization, the training of occupational skills lacks emphasis. Students know everything a little, but do not master complete occupational skills. Their occupational skills are only in the theoretical level. They do not know how to start in practice. For example, head teacher skill is a requisite occupational skill of students in teacher training major. Though students know what a head teacher should do, they feel that they can do nothing when taking an internship as head teacher in a secondary school or primary school and they do not know how to manage classroom discipline, coordinate students' conflicts and manage each student well.

\section{Reform of educational methods for occupational skills}

\section{Combination of education of occupational skills and professional teaching}

First, reduce professional theoretical courses, add practical courses, integrate contents of education of occupational skills into professional learning contents, promote the integration of students' knowledge and the integration of teaching contents and gradually improve professional teaching contents and educational contents of occupational skills. College teachers should communicate with teachers in primary and secondary schools positively and discuss and study curriculum system of normal university students.

Second, integration of occupational skills education examination and professional teaching test. Schools should establish a good evaluation mechanism for students, establish multiple evaluation indicators and contents, comprehensively evaluate students' subject-specific achievement and the performance of occupational skills and evaluate their learning attitude and emotion. The integration of both evaluations promotes students to understand themselves better, improve their deficiencies and realize self-improvement.

\section{Matching between the education of occupational skills and reform of basic education}

The education of occupational skills of normal university students should match with the current reform of basic education so as to train more high-quality teachers-to-be meeting social demands. It is required to explore students' psychological features, interests and hobbies and character, summarize methods for guiding students to produce learning motivation, inspire students to study consciously, establish a good relation between students and teachers, exert the function of college teachers of teaching by personal example as well as verbal instruction and promote the training of students' language expression ability, written expression ability, speech, sociability and appetency. For example, students can learn mandarin in the first semester. Besides speaking mandarin in class, students should develop the habit of speaking mandarin in daily life and correct errors consciously. In the second semester, role playing class can be implemented, including the simulation of theme class meeting and family visit. Calligraphy class should be set up in sophomore year. Students should be asked to train their pen writing, chalk writing and brush pen writing in calligraphy laboratory room.

Strengthen the cooperation with primary and secondary schools and provide more internship opportunities for students

Normal university students will work as teachers in primary and secondary schools. This requires colleges and universities to strengthen the cooperation with primary and secondary schools positively, make teaching contents closer to the reality and social demands, strengthen the school-running vitality of colleges and universities and realize win-win of colleges and primary and secondary schools. Students can take an internship or be on probation in primary and secondary schools in spare time to perceive teaching activities of teachers in primary and secondary schools in field, understand the occupation of teacher better in the communication with teachers in primary and secondary 
schools and understand characteristics of primary and secondary school education. Besides the training of students' occupational skills, strengthening the cooperation with primary and secondary schools can also provide more employment opportunities for students. It is required to take recommendation for employment as the key link in the cooperation, impel students to improve themselves and expand students' employment channels.

\section{Build an experimental base and provide good conditions for the education of occupational skills}

It is required to build a professional experimental base for on-campus occupational skills training according to students' professional features, supply advanced software and hardware facilities, such as microteaching classroom, audio-visual classroom, teachers' etiquette classroom and calligraphy training classroom and establish a systematic learning database through campus network. These data can be essential data accumulated by teachers or free resources obtained by teachers on the internet or professional resources purchased by schools. Meanwhile, schools should improve the learning database with the integration of professional disciplines and modern information technology. With the development of educational business, schools can also integrate some data in students' practical training into the database.

\section{Video teaching method}

Video teaching method is a practical training teaching completed with students' demonstration or teachers' demonstration through teaching video. College teachers generally divide teaching video into three categories: teaching video of excellent teachers, qualified video in students' training and video with many problems in students' training.

For example, teachers can play a teaching video of excellent teachers and ask students to imitate teachers' language, speech and teaching methods after watching the video. In this process, teachers should play a role of guidance and stimulate students' enthusiasm for imitation, which can gradually improve students' prelection skills in the long run. Meanwhile, teachers should prepare adequate text data in combination with the video during the guidance and make students understand various principles in teaching rapidly.

\section{Standardize contents of occupational skills training and stress the key point}

The training of occupational skills is a progressive process. Contents should not be large and all inclusive or small and comprehensive. It is required to conduct the training of occupational skills with key point. Contents of the training of occupational skills can be divided into the following aspects:

First, declarative and procedural contents. Declarative contents refer to "what it is", mainly including linguistics, educational psychology and humanities and social science etc. Procedural contents refer to "how to do it". Besides the knowledge in the textbook, the key point should be how to behave and learn. Attention should be paid to the training of students' consciousness, thus allowing them to develop good learning habits and consciousness and form the concept of lifelong learning.

Second, regular training and new skills training. Colleges and universities should keep up with market development, explore connotations of teaching reform in primary and secondary schools and see if it is necessary to add some new skills. For example, currently, primary and secondary schools use many multimedia teaching tools. Training contents of skills of development, design, making and use of multimedia courseware should be added in teaching.

Third, preliminary training of new skills. The development of any skill is a long-term process. It is impossible to make students master an occupational skill through decades of classes in a semester. Therefore, some preliminary trainings can be added in the training process of new skills so as to make preparations for students' skill use after they take up their quarters.

\section{Combination of occupational skills education and campus activities}

Teachers can carry out some campus practical activities and social practical activities in spare time and allow students to participate in practice. For example, teachers can organize students for social investigation on some schools in pilot reform of basic education and ask students to analyze various contents of educational reform and write a professional thesis with respect to the investigation content. This can not only stimulate students' interest in learning, but also allow them to have clearer understanding of their future employment and promote the training of their occupational skills. 


\section{Conclusion}

There are some problems in the teaching of occupational skills of normal university students. Graduates have low occupational skills. This influences the development of basic education and the employment of graduates. Colleges and universities should see various contents for the reform of basic education, endeavor to realize the reform of education of occupational skills, train students' occupational skills comprehensively and train more high-quality teachers-to-be for the society.

\section{Acknowledgments}

This paper is a project funded by Sichuan Educational Development Research Center in 2011, No.: CJF011032.

\section{References}

[1] Zhao Zhenyu, Wang Fenglan, Ma Jianing: Research on Training of Occupational Skills of Normal University Students, Teaching of Forestry Region, 2013(2).

[2] Lu Jia: Thinking on Strengthening Education of Occupational Skills of Normal University Students, Chinese Out-of-school Education, 2012(2).

[3] Yuan Xinlei: Brief Analysis on Training of Occupational Skills of Normal University Students and Research on Innovative Reform, Modern Enterprise Education, 2012(13).

[4] Bai Min: Establishment of Training Mode of Occupational Skills of Normal University Students, Journal of Sichuan College of Education, 2010,26(4).

[5] Di Xiaoyu: Theoretical Exploration and Practice of Training Mode of Occupational Skills of Normal University Students - Discussion on “One-Body Three-Wing” Training Mode of Teacher Education, Journal of Zhaoqing University, 2011,32(6). 